\title{
Antimicrobial activity of Davilla elliptica St. Hill (Dilleniaceae)
}

\author{
D.C. Michelin ${ }^{1}$, S.M. Iha ${ }^{1}$, D. Rinaldo' ${ }^{2}$ M. Sannomiya ${ }^{2}$, L.C.Santos ${ }^{2}$, W. Vilegas ${ }^{2}$, \\ H.R.N. Salgado ${ }^{*}$ \\ ${ }^{1}$ Departamento de Fármacos e Medicamentos, Faculdade de Ciências Farmacêuticas, UNESP, 14801-902, \\ Araraquara, SP, Brasil, \\ ${ }^{2}$ Departamento de Química Orgânica, Instituto de Química de Araraquara, UNESP, \\ 14800-900, Araraquara, SP, Brasil
}

\begin{abstract}
Davilla elliptica St. Hill ("lixinha”), family Dilleniaceae, is commonly used in the Brazilian folk medicine as purgative and stimulant. This work evaluated the antimicrobial activity of the methanol and chloroform extracts of the leaves and barks of D. elliptica using the discdiffusion method. The results obtained showed that the methanolic extracts of the leaves and barks presented antimicrobial activity against the tested microorganisms.
\end{abstract}

Keywords: Davilla elliptica, Dilleniaceae, antimicrobial activity.

\section{INTRODUCTION}

Davilla elliptica St. Hill (Dilleniaceae) is a native species from Brazil, which is popularly known as 'lixinha' (http://www.propp.ufu.br/revistaeletronica/ b/ocorrencia.pdf, 2003). There are properties attributed to $D$. elliptica with indications such as purgative and stimulant (Rodrigues; Carvalho, 2001). Phytochemical investigations of different parts of Davilla species have revealed the presence of $\alpha$-tocoferol, and the flavonoids myricetin, quercetin, myricetin-3-O- $\alpha$-L-rhamnoside, quercetin-3-O- $\alpha$-L-rhamnoside, kaempferol (Gurni; Kubitzki, 1981), as well as saponins and mucilage (Matheucci, 1996).

Despite the popular use of $D$. elliptica as a medicinal plant, there are no data about the antimicrobial effect of leaf extracts. Thus, the interest in this plant is justifiable because of its potential medicinal value. The present study has the aim of evaluating the antimicrobial activity of $D$. elliptica extracts obtained from the leaves and barks using the disc-diffusion method. It was also made a phytochemical screening of the chloroform and methanol extracts of the leaves and barks of $D$. elliptica by TLC on Si gel.

\section{MATERIAL AND METHODS}

\section{Microorganisms}

Eight microbial species taken from international collections were analyzed. The bacteria Bacillus subtilis (ATCC 9372), Bacillus cereus (ATCC 14579), Shigella spp (IAL 1578), Sthaphylococcus epidermidis (ATCC 12226), Proteus mirabilis (CDC 305), Salmonella spp (ATCC 19196), Enterococcus faecalis (ATCC 29212), and the yeast Candida albicans (ATCC 10231).

\section{Plant material}

Plant samples were collected in Porto Nacional, State of Tocantins, Brazil, in August 2002. The plant was identified and authenticated by Dra. Solange Lolis of the Universidade de Tocantins. A voucher specimen (No. 4583) was deposited at the Herbarium of the Universidade de Tocantins (HTO), campus of Porto Nacional.

\section{Extract preparation}

The air-dried and powdered leaves $(2.0 \mathrm{~kg})$ and barks $(2.0 \mathrm{~kg})$ of $D$. elliptica were extracted separately and exhaustively with $\mathrm{CHCl}_{3}$ and $\mathrm{MeOH}$ successively at room temperature (48 $\mathrm{h}$ for each solvent). Solvents were evaporated at $60{ }^{\circ} \mathrm{C}$ under reduced pressure affording the extracts coded as $\mathrm{ECHCl}_{3}(55.8 \mathrm{~g}$ of the barks and 103.5 $\mathrm{g}$ of the leaves) and $\mathrm{EMeOH}$ (289.8 $\mathrm{g}$ of the barks and $373.8 \mathrm{~g}$ of the leaves).

\section{Phytochemical screening}

The chromatographic analyses were made by TLC on Si gel eluted with different solvent systems: hexane/ethyl acetate (85:15, v:v), chloroform/methanol/ $n$-propanol/water (5:6:1:4, v:v:v:v) and chloroform/ methanol (85:15, v:v).

The flavonoids were identified by their intense coloration in ultraviolet light ( $254 \mathrm{~nm}$ ) when revealed with the NP/PEG (diphenylaminoborate/polyethyleneglycol) reagent (Wagner et al., 1984) eluted with chloroform/ methanol (85:15, v:v). Authentic standards (Sigma) of the existing flavonoids in our laboratory (quercetin, myricetin and kaempferol) were also used.

The tests for tannins were made according to the proceedings described by Simões et al. (2001) by means of the reaction with the gelatin and Schneider (1990) in

ISSN 0102-695X 
Table 1. Phytochemical screening of $D$. elliptica

\begin{tabular}{l|c|c|c|c}
\hline \multirow{2}{*}{ Test } & \multicolumn{2}{|c|}{ Leaves } & \multicolumn{2}{c}{ Barks } \\
\cline { 2 - 5 } & $\mathrm{ECHCl}_{3}$ & $\mathrm{EMeOH}$ & $\mathrm{ECHCl}_{3}$ & $\mathrm{EMeOH}$ \\
\hline Catechins & - & + & - & + \\
Tannins & - & + & - & + \\
Gallic acid & - & + & - & - \\
Flavonoids & - & + & - & - \\
Saponnins & - & - & + & - \\
Terpenes & + & + & - \\
\hline
\end{tabular}

$\mathrm{ECHCl}_{3}=$ chloroformic extract; $\mathrm{EMeOH}=$ methanolic extract; absent $=(-)$; present $=(+)$

Table 2. Antimicrobial activities of the methanolic extracts of $D$. elliptica.

\begin{tabular}{|c|c|c|c|c|c|c|c|c|}
\hline \multirow{3}{*}{ Microorganisms } & \multicolumn{6}{|c|}{ Extracts $(\mathrm{mg} / \mathrm{mL})$} & \multicolumn{2}{|c|}{ Positive controls (mg/disc) } \\
\hline & \multicolumn{3}{|c|}{$\begin{array}{c}\mathrm{EMeOH} \\
\text { leaves }\end{array}$} & \multicolumn{3}{|c|}{$\begin{array}{c}\mathrm{EMeOH} \\
\text { barks }\end{array}$} & \multirow{2}{*}{$\begin{array}{c}\text { Cipro. } \\
5\end{array}$} & \multirow{2}{*}{$\begin{array}{c}\text { Keto } \\
40\end{array}$} \\
\hline & 50 & 75 & 100 & 50 & 75 & 100 & & \\
\hline S. epidermidis & - & - & - & - & - & - & 25 & NT \\
\hline B. subtilis & 12 & 13 & 13 & 9 & 9 & 10 & 20 & NT \\
\hline B. cereus & 11 & 11 & 12 & 9 & 9 & 9 & 20 & NT \\
\hline E. faecalis & 9 & 10 & 12 & - & - & - & 22 & NT \\
\hline Shigella spp & 11 & 12 & 12 & 8 & 8 & 9 & 22 & NT \\
\hline P. mirabilis & - & - & - & - & - & - & 22 & NT \\
\hline Salmonella spp & 12 & 14 & 14 & - & - & - & 22 & NT \\
\hline C. albicans & 11 & 12 & 13 & 8 & 9 & 9 & NT & 16 \\
\hline
\end{tabular}

Diameter of zone (mm), (-) negative; NT: not tested ; Cipro.: ciprofloxacin; Keto.: ketoconazole

Table 3. Minimum inhibitory concentration (MIC) exhibited by the D. elliptica $\mathrm{MeOH}$ extracts

\begin{tabular}{lcc}
\hline \multicolumn{1}{c}{ Microorganisms } & MIC (mg/mL) & EMeOH \\
& Barks \\
\cline { 2 - 3 } S. epidermidis & leaves & NT \\
B. subtilis & $\mathrm{NT}$ & 1.25 \\
B. cereus & 1.25 & $\mathrm{NT}$ \\
E. faecalis & $\mathrm{NT}$ & $\mathrm{NT}$ \\
Shigella spp & 5.0 & 2.5 \\
P. mirabilis & 1.25 & $\mathrm{NT}$ \\
Salmonella spp & $\mathrm{NT}$ & $\mathrm{NT}$ \\
C. albicans & 5.0 & 5.0 \\
\hline
\end{tabular}

NT: not tested

the reaction with iron salts.

Iodine vapor and solution of $\mathrm{CeSO}_{4}$ were also used (saponnins and terpenes) as well as anisaldehyde/ sulfuric acid solution for the detection of flavonoids, terpenes, saponnins, gallic acid and catechins (Wagner et al., 1984).

The compounds classes found in the $\mathrm{ECHCl}_{3}$ and $\mathrm{EMeOH}$ leaves and barks of D. elliptica are indicated in Table 1.

\section{Disc diffusion method}

The dried plant extracts of leaves and barks were dissolved in the same solvent $\left(\mathrm{MeOH}\right.$ and $\left.\mathrm{CHCl}_{3}\right)$ to a final concentration of $30 \mathrm{mg} / \mathrm{mL}$. Then they were sterilized by filtration through $0.45 \mu \mathrm{m}$ Millipore filters. Antimicrobial tests were carried out by the disc diffusion method (Bauer et al., 1966).

The microorganism cultures were grown in Brain Heart Infusion liquid medium at $37^{\circ} \mathrm{C}$. After $6 \mathrm{~h}$ of growth, each microorganism culture, at a concentration of $10^{6}$ cells $/ \mathrm{mL}$, was inoculated on the surface of Mueller- 
Hinton agar plates $(100 \mu \mathrm{L})$. Subsequently, filter papers discs (6 mm in diameter) saturated with extracts $(20 \mu \mathrm{L})$ were placed on the surface of each inoculated plate, in Brain Heart Infusion solid medium. The plates were incubated at $35^{\circ} \mathrm{C}$ for $24 \mathrm{~h}$ for bacteria and for $48 \mathrm{~h}$ for $C$. albicans. After this period, the zones of growth inhibition around the discs were measured. Overall, cultured microorganisms with halos equal to or greater than $7 \mathrm{~mm}$ were considered susceptible to the tested extract.

The negative control was the solvent used and the positive control was ciprofloxacin ( $5 \mu \mathrm{g} / \mathrm{disc}$ ) for bacteria and ketoconazole (40 $\mu \mathrm{g} / \mathrm{disc})$ for $C$. albicans. All determinations were made in duplicate.

\section{Minimum inhibitory concentration}

The minimum inhibitory concentration (MIC) was determined by the dilution method according to National Committee for Clinical Laboratory Standards (NCCLS, 2003). The bacteria were grown in nutrient broth (Brain Heart Infusion liquid medium) for $6 \mathrm{~h}$. After that, $20 \mu \mathrm{L}$ of $10^{6}$ cells $/ \mathrm{mL}$ were inoculated in tubes with nutrient broth supplemented with eight different concentrations $(25,50,100,200,400,500,600$ and $800 \mu \mathrm{L}$ ) of the extracts. After $24 \mathrm{~h}$ at $37^{\circ} \mathrm{C}$, the MIC of each sample was measured by the optical density in the spectrophotometer $(620 \mathrm{~nm})$, by comparison of the sample readout with the non inoculated nutrient broth (Nascimento et al., 2000). All determinations were made in duplicate.

\section{RESULTS AND DISCUSSION}

A total of 8 microorganisms, which consisted of 7 bacteria and 1 yeast, were tested and the results are summarized in Tables 2 and 3. The $\mathrm{ECHCl}_{3}$ extract of $D$. elliptica leaves and barks did not show any activity and the results are not shown.

As can be observed in Table 2, the EMeOH of D. elliptica leaves and barks possessed the antimicrobial activity against the microorganisms tested. In the assays against the microorganisms by the agar diffusion method (Table 2), the mean zones of inhibition obtained were between 8 to $14 \mathrm{~mm}$.

Both the EMeOH of $D$. elliptica leaves and barks were active against $B$. subtilis, $B$. cereus, Shigella spp and C. albicans. However, in the extracts of the leaves the observed activity was higher. We also observed the antibacterial activity of the $\mathrm{EMeOH}$ leaves against $E$. faecalis and Salmonella spp (Table 2).

The EMeOH of $D$. elliptica leaves showed activity against six different species of microorganisms, while the $\mathrm{EMeOH}$ of $D$. elliptica barks showed activity against four different species of microorganisms (Table 2).

The MIC values obtained were ranged between 1.25 to $5.0 \mathrm{mg} / \mathrm{mL}$ (Table 3). The best results were observed for the EMeOH leaves and barks against $B$. subtilis and $\mathrm{EMeOH}$ leaves against Shigella spp with all of them showing MIC at $1.25 \mathrm{mg} / \mathrm{mL}$ (Table 3).

Tannins, gallic acid, some catechins and flavonoids can show antimicrobial activity (Scalbert, 1991; Veluri et al., 2004; Bylka et al., 2004; Harborne et al., 2000). Therefore, the presence of such compounds classes in the EMeOH leaves and barks of the D. elliptica might be responsible for the antimicrobial activity.

\section{ACKNOWLEDGEMENTS}

PADC-FCF, FAPESP and CNPq - Brazil

\section{REFERENCES}

Bauer AW, Kirby MDK, Sherries JC, Truck M 1966. Antibiotic susceptibility testing by a standardized single disk method. Am J Clin Pathol 45: 493-496.

Bylka W, Matlawska I, Pilewski NA 2004. Natural flavonoids as antimicrobial agents. J Am Nutraceutical Assoc 7: 24-31.

Gurni AA, Kubitzki K 1981. Flavonoid chemistry and systematics of the Dilleniaceae. Biochem Syst Ecol 9: 109-114.

Harborne JB, Williams CA 2000. Advances in flavonoids research since 1992. Phytochemistry 55: 481-504.

http://www.propp.ufu.br/revistaeletronica/b/ocorrencia.pdf, acessado em outubro de 2003.

Matheucci LG 1996. Estudo farmacognóstico e farmacológico de Davilla rugosa Poiret. São Paulo, 75p. Dissertação de Mestrado - Faculdade de Ciências Farmacêuticas, Universidade de São Paulo.

Nascimento GGF, Locatelli J, Freitas PC, Silva GL 2000. Antibacterial activity of plant extracts and phytochemicals on antibiotic-resistant bacteria. Braz J Microbiol 31: 247-256.

NCCLS (National Committee for Clinical Laboratory Standards) Performance Standards for Antimicrobial Disc Susceptibility Tests 2003. Approved Standard M2-A7, Wayne, Pennsylvania.

Rodrigues VEG, Carvalho DA2001. Levantamento etnobotânico de plantas medicinais no domínio do cerrado na região do Alto Rio Grande - Minas Gerais. Ciênc Agrotec 25: $102-123$

Scalbert A 1991. Antimicrobial properties of tannins. Phytochemistry 30: 3875-3883.

Schneider G 1990. Arzneidrogen. Ein kompendium für pharmazeuten, biologen und chemiker. Mannheim: Wissenschaftsverlag.

Simões CMO, Schenkel EP, Gosmann G, Mello JCP, Mentz LA, Petrovick PR 2001. Farmacognosia, da planta ao medicamento. 3. ed, Porto Alegre / Florianópolis: Ed. Universidade/ UFRGS, Ed. da UFSC.

Veluri R, Weir TL, Bais HP, Stermitz FR, Vivanco JM 2004. Phytotoxic and antimicrobial activities of catechin derivatives. J Agric Food Chem 52: 1077-1082.

Wagner HM, Bladt S, Zgainki EM 1984. Plant drug analysis. Berlin: Springer.

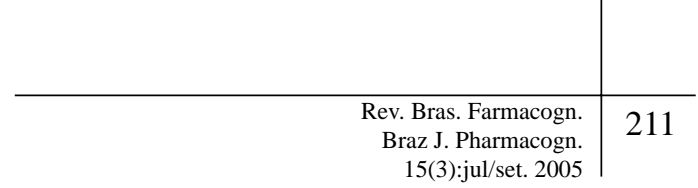

